\title{
FOOD ESTATE SEBAGAI KETAHANAN PANGAN DI TENGAH PANDEMI COVID-19 DI DESA WANASABA
}

\author{
Baiq Rani Dewi Wulandani'1), Wiwin Anggraini²) \\ 1)Fakultas Peternakan Universitas Mataram, Mataram, NTB, Indonesia \\ ${ }^{2)}$ Fakultas Pertanian Universitas Mataram, Mataram, NTB, Indonesia \\ Corresponding author: Baiq Rani Dewi Wulandani \\ Email: baiq.rani@unram.ac.id
}

\section{Diterima 03 Oktober 2020, Direvisi 19 Oktober 2020, Disetujui 19 Oktober 2020}

\begin{abstract}
ABSTRAK
Dampak dari pandemi covid-19 telah mengganggu berbagai aspek kehidupan mulai kesehatan,sosial,ekonomi dan beragam lain sebaginya, di sebagian besar belahan dunia khususnya di Indonesi. Salah satu persoalan utamanya adalah berkenaan ketahanan pangan yang saat ini menjadi sangat ramai dalam perbincangan public sebagai konsekuensi dari pandemic covid-19 yang semakin meluas khususnya di Negara Indonesia. Pangan adalah suatu tonggak utama bagi kebutuhan masyarakat Indonesia, maka dari itu pentingnya perhatian khusus dari banyak pihak dalam upaya memenuhi kebutuhan masyarakat dan tentang bagaimana untuk mengantisipasi ketahanan pangan di masa pandemic covid-19. food estate merupakan salah satu strategi yang kompatibel untuk diaplikasikan dalam situasi pandemi, di mana wabah penyakit merupakan bentuk ancaman non konvensional bagi ketahanan nasional. Ketahanan pangan Indonesia menjadi salah satu isu geopolitik domestik yang mengemuka, di mana pengelolaannya masih jauh dari kata memuaskan.
\end{abstract}

Kata kunci: ketahanan pangan, food estate

\begin{abstract}
The impact of the Covid-19 pandemic has disrupted various aspects of life from health, social, economy, and various others, in most parts of the world, especially in Indonesia. One of the main problems is with regard to food security which is currently very busy in public discussion as a consequence of the COVID19 pandemic which is increasingly widespread, especially in Indonesia. Food is a pillar primary for the needs of the Indonesian people, therefore the importance of special attention from many parties in an effort to meet the needs of the community and on how to anticipate food security during the Covid-19 pandemic. Food estate is a strategy that is compatible to be applied in a pandemic situation, where disease outbreaks are a form of non-conventional threat to national security. Indonesian food security is one of the emerging domestic geopolitical issues, where its management is still far from satisfactory.
\end{abstract}

Keywords: food security, food estate

\section{PENDAHULUAN}

Virus corona (covid-19) merupakan penyakit menular yang tengah menyebar dan sekurang-kurangnya telah menginfeksi 1 juta orang dan sebanyak $90 \%$ negara di dunia telah menjadi korban. Kemunculan virus corona mulai terdeteksi pertama kali di negara China pada awal Desember tahun 2019. Kala itu, sejumlah pasien berdatangan ke rumah sakit di Wuhan dan melaporkan bahwa ada gejala penyakit yang tidak dikenal. Setelah melalui kegiatan diketahui bahwa terdeteksi adanya varian virus baru dari virus yang telah dikenal oleh dunia kedokteran sebelumnya sebagai Severe Acute Respiratory
Syndrom Corona Virus 2 (SARS-Cov-2). Kemudian melalui rilis pers yang dikeluarkan Rabu (11/3) lalu, organisasi kesehatan dunia (WHO) memberikan pernyataan bahwa status penularan virus corona dari varian virus yang dikenal dengan istilah COVID-19 telah menjadi status pandemi, karena dinilai bahwa wabah ini sudah sampai tingkat penyebaran dan keparahan yang mengkhawatirkan. Akibat dari pernyataan tersebut beberapa negara mulai menetapkan status kedaruratan kesehatan masyarakat terkait wabah virus corona (COVID-19) khususnya di negara Indonesia, karena berdasarkan faktor resiko yang ada. Selain melibatkan kedaruratan 
kesehatan masyarakat, banyak aspek yang mendapatkan konsekuensinya seperti di bidang sosial, politik, ekonomi, dan sebagainya.

Segala aspek pencegahan dan penanggulangan telah dilakukan oleh berbagai pihak di seluruh dunia terhadap pandemi yang terjadi sejak bulan Maret 2020 samapi dengan saat ini. Upaya yang telah dilakukan tersebut saat ini telah membuahkan hasil dan telah begeser dari masa pandemi menjadi cenderung kearah normal baru semenjak ditetapkannya karantina wilayah (lock down) dibeberapa negara. Juga melalui Pembatasan Sosial Bersekala Besar (PSBB) yang dilakukan oleh pemerintah Indonesia, seperti hal adanya himbauan kepada masyarakat untuk melakukan pembatasan sosial misalnya dengan melakukan beragam aktivitas dirumah dan mengurangi kontak fisik. Virus ini mengganggu banyak sekali sektor-sektor yang menyokong kehidupan masyarakat, termasuk diantaranya sektor pertanian.

Sektor pertanian menjadi sorotan karena memiliki kaitan erat dengan ketahanan pangan nasional. Tentunya pada masa pandemi yang sulit seperti sekarang ini ketahanan pangan menjadi sesuatu yang harus diupayakan untuk menghindar dari krisis pangan yang seakan menghantui Indonesia. Dari sini petani sebagai tonggak utama pada pemenuhan pangan masyarakat juga merasakan dampaknya. Seperti harus memenuhi permintaan yang cukup tinggi, menjamin kualitas produk, jalur distribusi, dan banyak hal-hal lain yang membutuhkan penyesuaian strategi agar pemenuhan kebutuhan pangan masyarakat dan ketahanan pangan pada masa pandemi di indonesia tetap terjamin.

Dalam lingkup domestic nasional, virus corona covid-19 memberikan dampak yang besar. Seluruh aspek ideologi, politik, keamananpertahanan,ekonomi, dan sosial-budaya bangsa mengalami penyesuaian secara massif menyusul perubahan revolusioner yang dibawa oleh pandemic covid-19. Dikarenakan sifat ancamannya yang membutuhkan koordinasi antarsektor komponen Negara, presiden Joko Widodo mengeluarkan Peraturan Presiden Nomor 82 Tahun 2020 tentang Komite Dalam reaktivasi program lumbung pangan, selain pengembangan sentra produksi, pemerintah mengembangkan sistem penyimpanan cadangan pangan cadangan dan sistem distribusi. Reaktivasi ini dinyatakan bukan sebagai program cetak sawah tetapi sebagai pengembangan pusat pangan. Pengembangan food estate mencakup tanaman singkong,
Penanganan Coronavirus Disease 2019 (COVID19) dan Pemulihan konomi Nasional. Pemerintah Indonesia mengembangkan program Food Estate sebagai salah satu ujung tombak dalam strategi ketahanan pangan di masa pandemi covid-19.

\section{METODE}

Kegiatan ini dilakukan dengan metode survei dan wawancara guna menjawab permasalahan berupa kemungkinan krisis pangan yang terjadi pada era pandemi COVID19. Mengingat kebaruan isu yang masih sangat baru, kegiatan ini berfokus pada data-data dan variabel terkini mengenai ketahanan pangan di Indonesia. Termasuk pula didalamnya, berkaitan dengan cadangan pangan Indonesia setidaknya dalam periode lima tahun terakhir. Karakteristik positivisme juga ditegaskan dengan penggunaan data-data empirik dalam memenuhi tujuan kegiatan ini, yaitu untuk menegaskan dukungan terhadap kebijakan proyek food estate dan memberikan usulan kepada institusiinstitusi terkait untuk mengedepankan ketahanan pangan sebagai strategi non konvensional dalam menghadapi ancaman pandemi.

Studi kasus dalam kegiatan ini merujuk pada kasus-kasus di mana pandemi menjadi fenomena global yang mengancam keamanan manusia (human security), khususnya apabila dianalisis dari perspektif ketahanan pangan. Tidak dapat dipungkiri bahwa aspek-aspek di atas ketahanan pangan, ketahanan nasional, dan keamanan manusia--merupakan konsep yang saling berkaitan erat dan apabila terjadi disrupsi pada salah satu di antaranya, aspek lainnya akan turut terpengaruh.

Teknik pengambilan data dilakukan dengan survey, wawancara dan dokumentasi. Survey dilakukan untuk melihat langsung kondisi ketahanan pangan masyarakat Desa Wanasaba terhadap bentuk pemanfaatan lahan pekarangan yang dikembangkan oleh masyarakat dan untuk mengambl dokumentasi berupa foto dari bentuk pemanfaatan lahan pekarangan tersebut.

\section{HASIL DAN PEMBAHASAN Food Estate ketahanan pangan}

jagung, dan kebutuhan-kebutuhan pangan pokok lainnya. Sebagaimana telah didefinisikan oleh Komite Ketahann Pangan Dunia Perserikatan Bangsa-Bangsa, ketahanan pangan merupakan situasi dimana semua orang dan dalam keadaan bagaimanapun memiliki akses fisik, sosial, dan ekonomi terhadap pangan, yang tidak saja harus cukup dan juga aman dan bergizi. Pangan 
tersebut juga harus memenuhi kebutuhan dan preferensi diet harian, sesuai dengan standar kehidupan aktif serta sehat. Mengingat kasus pandemic covid-19 dapat di ambil pelajaran bahwa ketahanan pangan suatu negara terancam apabila terjadi krisis pangan global yang berdampak kepada harga dan suplai pangan di pasar internasional, dan selanjutnya negara tersebut memiliki pendapatan per kapita yang rendah, persentase pemasukan untuk pangan diatas 35 persen, serta ketidakmampuan pengampu kebijakan ketahanan pangan untuk beradaptasi dengan gejolak global (Alfiky dkk, 2012).

Pada akhirnya, pengembangan food estate yang dapat memberikan serapan lapangan pekerjaan di sektor non pertanian dapat mengurangi angka kemiskinan nasional, di mana pertumbuhan ekonomi yang dimotori oleh sektor pertanian lebih efektif untuk mengurangi kemiskinan dibandingkan dengan kepemimpinan sektor konstruksi dan manufaktur (Loayza and Radatz, 2006). Secara keseluruhan, pengembangan food estate dapat meningkatkan pemasukan per kapita serta menurunkan persentase pemasukan untuk kebutuhan pangan sehari-hari, yang pada dasarnya, sangat penting apabila pemerintah ingin memiliki lebih banyak opsi kebijakan apabila terjadi krisis pangan global akibat pandemi COVID-19. Namun setidaknya, ketahanan pangan yang ditopang oleh produksi domestik dapat mengurangi dampak yang ditimbulkan dari gejolak dunia internasional, dan potensi ancaman konflik yang ditimbulkan dari hancurnya ketahanan pangan nasional dapat dihindari; atau setidaknya, dapat dimitigasi.

\section{Ketersedian Lahan Dan Pangan Rumah Tangga}

Setelah melakukan survei dan wawancara terhadap kasus dari ketahanan pangan di tengah pandemi covid-19 terhadap ketersediaan pangan rumah tangga masyarakat di Desa Wanasaba Kecamatan Wanasaba.

Hasil kegiatan memberikan gambaran bahwa produksi dan ketersediaan pangan di Desa Wanasaba Kabupaten Lombok Timur memiliki hubungan yaitu jumlah produksi pangan tersebut mempengaruhi jumlah ketersediaan pangan dari aspek ketersediaan energi dan protein. Mengingat kasus pandemi covid-19 semua sektor terlebih sektor pertanian ketersediaan akan pangan sangat menurun drastis akibat pandemi covid-19. Dari kegiatan ini diperoleh $25 \%$ responden yang telah memanfaatkan lahan pekarangan rumah untuk bercocok tanam untuk meningkatkan kebutuhan pangan mereka sehari-hari di tengah pandemi covid-19. Mengingat lahan pekarangan masyarakat Desa Wanasaba banyak yang kosong hal tersebut memberikan perhatian mendalam terhadap kami segenap Mahasiswa KKN Kebencanaan Universitas Mataram untuk ikut andil dalam melakukan pergerakan mahasiswa terhadap pemanfaatan ketersediaan lahan untuk kebutuhan pangan masyarakat Desa Wanasaba dengan melakukan pembagian bibit sawi dan bayam untuk meninjau pengembangan Food Estate atau lumbung pangan nasional terhadap masyarakat. Food Estate merupakan konsep pengembangan pangan yang di lakukan secara terintegrasi mencakup pertanian, perkebunan, bahkan peternakan di suatu kawasan.
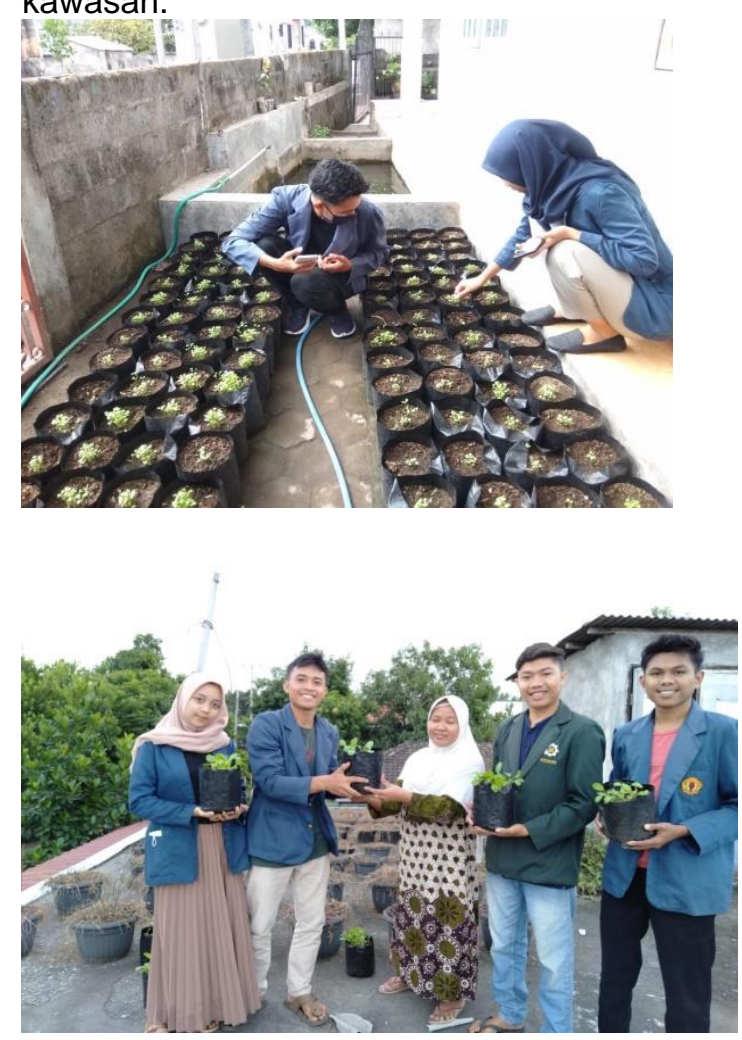

Gambar 1. Kegiatan penyerahan bibit.

Dari data kegiatan $25 \%$ responden yang memanfaatkan lahan pekarangan rumah sebagai ketahanan pangan di tengah pandemi dengan tujuan untuk meningkatkan kebutuhan pangan sehari-hari dengan mudah. Adapun data angket yang telah terkumpul, penulis oleh kedalam tabletabel sebagai berikut:

Tabel 1. Respon Masyarakat Terhadap

Pemanfaatan Lahan Pekarangan Sebagai Ketahanan pangan Masyarakat Desa Wanasaba 


\begin{tabular}{lcc}
\hline \multicolumn{2}{c}{ Klarifikasi } & \\
$\begin{array}{l}\text { Frekuensi } \\
\text { Presentase }\end{array}$ & & \\
\hline Sangat setuju & 50 & $62,5 \%$ \\
Setuju & 30 & $37,5 \%$ \\
Kurang setuju & - & - \\
Tidak setuju & - & - \\
\hline \multicolumn{1}{l}{ Jumlah } & & 80 \\
& $100 \%$ & \\
\hline
\end{tabular}

Berdasarkan tabel 1 di atas, mengenai respon masyarakat terhadap pemanfaatan lahan pekarangan rumah sebagai ketahanan pangan dapat disimpulkan bahwa sebagian besar dari masyarakat Desa Wanasaba sangat berapresiasi dan memiliki respon positif terhadap lahan pekarangan yang dimanfaatkan dengan tujuan untuk meningkatkan ketahanan

pangan di tengah pandemi covid-19. Hal ini di buktikan oleh sebagian dari responden memilih sangat setuju dan setuju dari beberapa pilihan jawaban yang tersedia serta beberapa alasanalasan yang telah diberikan responden. Untuk lebih jelasnya adapun alasan-alasan tersebut dapat dilihat Tabel 2.

Tabel 2. Alasan Masyarakat Memanfaatkan Lahan Pekarangan

\begin{tabular}{|c|c|c|}
\hline \multicolumn{3}{|c|}{$\begin{array}{l}\text { Klarifikasi } \\
\text { Persentase }\end{array}$} \\
\hline Agar lahan tersebut tidak & 52 & $65 \%$ \\
\hline sia-sia & 10 & $12,5 \%$ \\
\hline Untuk mengisi & 18 & $22,5 \%$ \\
\hline $\begin{array}{l}\text { kekosongan di waktu } \\
\text { senggang }\end{array}$ & - & - \\
\hline $\begin{array}{l}\text { Berkurangnya lahan } \\
\text { (tanah) kosong yang di } \\
\text { garap } \\
\text { Lain -lain }\end{array}$ & & \\
\hline Jumlah & 80 & $100 \%$ \\
\hline
\end{tabular}

Berdasarkan tabel 2 di atas, dapat diketahui bahwa ada beberapa alasan masyarakat memanfaatkan lahan pekarangan yang dimiliki yaitu agar lahan tersebut tidak sia-sia, untuk mengisi kekosongan saja, dan berkurangnya lahan (tanah) kosong yang akan digarap. Namun dari beberapa alasan tersebut, sebagian besar dari masyarakat menjawab bahwa alasan mereka memanfaatkan lahan pekarangan tersebut adalah agar lahan tersebut tidak sia-sia dan jika dimanfaatkan dengan baik pasti akan memberikan keuntungan yang besar terutama untuk meningkatkan ketahanan pangan seharihari.
Berdasarkan hasil kegiatan yang dilakukan terhadap pengembangan foot estate ketahanan pangan masyarakat di Desa Wanasaba pada masa pandemi covid-19 merupakan peristiwa yang multisektoral dan dapat mendisrupsi sector strategis termasuk ketahanan pangan masyarakat. Sejumlah kasus yang telah di analisis telah membuktikan bahwa pandemic dan ancaman terhadap ketahanan pangan merupakan dua isu yang sangat terpisahkan. Dampak tersebut timbul bahkan terjadi terhadap ketahanan pangan masyarakat telebih di Desa Wanasaba. Disinilah peran penting mahasiswa untuk memberikan semangat serta ikut andil dalam kasus ketahanan pangan rumah tangga. Sehingga masyarakat dapat memanfaatkan lahan pekarangan yang di miliki sebagai proyek food estate misalkan untuk pertanian atau perkebunan seperti perkebunan manga, pisang dan lain sebagainya. Peternakan seperti peternakan sapi, kambing, ayam, itik, ikan tawar dan jenis lainnya sebagai bentuk upaya masyarakat untuk menyokong ekonomi di tengah pandemi covid-19.

\section{SIMPULAN}

Berdasakan hasil kegiatan dan pembahasan dapat di ambil suatu kesimpulan bahwa ada banyak bentuk pemanfaatan lahan pekarangan yang di kembangkan masyarakat pada lahan pekarangan yang di miliki misalkan untuk pertanian dan perkebunan sebagai upaya pengembangan food estate terhadap ketahanan pangan masyarakat Desa Wanasaba di tengah pandemi cobid-19. Dengan memanfaatkan lahan pekarangan masyarakat dapat melakukan penanaman tanaman sayuran atau sebagainya sebagai stok cadangan sumber daya alam yang harus di persiapkan dalam menghadapi kasus pandemi. Karena dengan memanfaatkan lahan pekarangan dapat berpengaruh terhadap peningkatan pendapatan masyarakat Desa Wanasaba.

Hal yang tak kalah penting, adalah bahwa proyek food estate yang dicanangkan oleh Pemerintah Indonesia pula menjadi perwujudan dari strategi ketahanan pangan nasional yang semakin krusial pada era pandemi, sebagaimana dalam beberapa waktu terakhir. Tidak hanya itu, pelaksanaan proyek food estate pula akan menyokong berbagai aspek lain seperti ekonomi masyarakat agraris, perwujudan keadilan sosialekonomi, hingga dapat meningkatkan pilihan kebijakan Pemerintah Indonesia dalam menghadapi berbagai situasi. 


\section{UCAPAN TERIMAKASIH}

Dengan hormat, sehubung dengan sudah terbitnya Jurnal Agro Dedikasi Masyarakat (Jurnal Nasional) volume 16 September 2020, saya selaku pemakalah oral mengucapkan terimakasih atas kerjasama Mahasiswa KKN Kebencanaan Unram 2020 yang sudah berpartisipasi dalam penyusunan jurnal ini dan tidak lupa saya mengucapkan terimakasih atas bantuan Masyarakat Desa Wanasaba yang bersedia menjadi mitra penyempurna naskah dalam menyampaikan pemikiran dalam melakukan wawancara.

\section{DAFTAR RUJUKAN}

Alfiky, A.,Kaule,G., \& Salheen, M. (2012). Agriculture Fragmentation of the Nile Delta; A Modeling Apporoach to Measuring Agricultural Land Deterioration in Egyptian Nile Delta. Procedia Environmental Sciences, 14, 79-97. Https://Doi.Org/10.1016/j.Proenv., n.d..

Bernauer, T., Böhmelt, T., \& Koubi, V. (2012). Environmental Changes and Violent Conflict. Environmental Research Letters, $\quad 7(1), \quad 015601$. Https://Doi.Org/10.1088/17489326/7/1/015601

Bernauer, T., Böhmelt, T., \& Koubi, V. (2012). Environmental Changes And, n.d.)

Buzan, B., Buzan, R. P. of I. S. C. for the S. of D. B., Etc, Wæver, O., Waever, O., \& Wilde, J. de. (1998). Security: A New Framework for Analysis. Boulder: Lynne Rienner Publishers, n.d.

Diwangkara, Catra (2020). Upaya Bela Negara Melalui Ketahanan Pangan Di Masa Pandemi Covid-19. Diakses 7 Juni 2020 Dari Http://Ssm.Com/Abstract=3621404 or

Http://Dx.Doi.Ord/10.2139/Ssm.3621404 ., n.d.

Food and Agriculture Organization. (2020). Impacts of Coronavirus on Food Security and Nutrition in Asia and the Pacific: Building More Resilient Food Systems (HIm. 9) [Policy Recommendation]. Bangkok. Diakses Pada 7, n.d.

Lenz-Raymann, K. (2014). Securitization Theory: Legitimacy in Security Politics. Dalam Counter-Terrorism and Freedom of Religion in Central Asia. Securitization of Islam: A Vicious Circle (HIm. 243-256). Transcript Verlag. JSTOR. Diakses 6 Agustus $2020 \mathrm{Da}$, n.d.
Loayza, N., \& Raddatz, C. (2006). The Composition of Growth Matters for Poverty Alleviation. Washington, DC: World Bank, n.d.

Oshaug, A., Eide, W. and Eide, A., 1994. Human Rights: A Normative Basis for Food and Nutrition-Relevant Policies. Food Policy, 19(6): 491-516., n.d.

Timur., P. D. W. K. W. K. L. T. 2010. M. D. W. K. W. K. L. (n.d.). Pemerintah Desa Wanasaba Kecamatan Wanasaba Kabupaten Lombok Timur. 2010. Monograffi Desa Wanasaba Kecamatan Wanasaba Kabupaten Lombok Timur.

Von Braun, J., Bouis, H., Kumar, S., \& PandyaLorch, R. (1992). Improving Food Security of the Poor. Washington, DC: IFPRI Institute. (n.d.). 